\title{
Research on the Problems of Tourism Industry Development in Northwest Minority Regions and the Countermeasures*
}

\author{
Juanjuan Chen \\ Tourism College \\ Northwest Normal University \\ Lanzhou, China 730000
}

\begin{abstract}
The tourism industry in northwest minority regions develops slowly due to the remote location and adverse natural condition of this region, the weak self-development ability, and this region has always been influencing by the national developmental strategy. However, northwest minority regions are of unique natural landscape, profound cultural and historical accumulation, and outstanding minority style characteristics. In addition, the implementation of modern "The Belt and Road" strategic conception enables the tourism industry of northwest minority regions to usher in the unprecedented development opportunity. Nevertheless, the tourism industry development of northwest minority regions still faces many problems. In this paper, the significance of developing tourism industry in northwest minority regions is illustrated, the problems faced by tourism industry development in northwest region currently are analyzed, and the countermeasures for tourism industry development in northwest minority regions are proposed.
\end{abstract}

Keywords-northwest minority regions; tourism industry; problems; countermeasures

\section{INTRODUCTION}

The comprehensive reform and opening up in 1978 has opened a new situation for the development of China's tourism industry. China's tourism research also has a history of 40 years along with the flourishing development of China's tourism industry. However, the involvement of ethnic tourism in tourism research starts from the publication of the paper of Develop Ethnic Tourism Commodity Actively by Jia Guangjie in 1987. At the beginning of ethnic tourism research, it is related to the economic development of minority area (Jiang Jie, 2015). In recent years, some scholars discuss the deep development and research of tourism industry in ethnic minority areas starting from the perspective of tourism industry development in ethnic minority areas and the factors influencing development, and they put forward the sustainable development countermeasures for the tourism industry in ethnic minority areas to carry out ecological tourism in these

\footnotetext{
*Project Name:

1.Funded by the project authorized by national nationality research committee 2017 (Project No.: 2017-GME-012)

2.Funded by young teacher scientific research capacity promotion program of Northwest Normal University 2015
}

regions (Zhao Jinguo, 2010); the researches about tourism industry in northwest minority regions mainly focus on the aspects such as current situation of tourism industry development in northwest region, tourism industry competitiveness, industry joint development and the sustainable development of this industry. Dou Kailong has not only studied the seven features of tourism resources in northwest minority regions, but also analyzed the disadvantages of tourism development in northwest minority regions (Dou Kailong, 2008). Ba Duoxun studies the impact on the society of sightseeing district by the tourism industry development of northwest minority regions, the national culture protection, tourism products supply and other aspects from the perspective of culture (Ba Duoxun, 2007). The tourism industry development in ethnic minority regions has attracted attention from more and more scholars after the strategic concept of "The Belt and Road" has been put forward Wang Zhishun holds the opinion that national cultural tourism forms an internal part of the economic development in minority area, and the important method for the economic development in the remote minority area (Wang Zhishun, 2016). Wang Jiaguo and Wu Zhongjun believe that "The Belt and Road" enables the ethnic minority regions to move towards the most leading edge, the important node and key hub from the rear, border area and ending of the reform and opening up. The tourism industry in the ethnic minority areas has ushered in an unprecedented development opportunity (Wang Jiaguo, Wu Zhongjun, 2016).

\section{SIGNIFICANCE OF RESEARCH ON TOURISM INDUSTRY DEVELOPMENT IN NORTHWEST MINORITY REGIONS}

Most of the ethnic minority regions are located in the remote area with adverse natural conditions, undeveloped economy and weak self-development ability. Moreover, it is influenced by the gradient development strategy for the east, central and west areas implemented by the state. The strategic position of ethnic minority areas has always been safeguarding national territorial integrity, national unity and border security, and more of the state's policies focus on the infrastructure improvement, economic development to solve people's difficulties in production and life, calming the public and consolidating frontier defense and other aspects. Up to now, 
ethnic minority region is still a weakness in building the moderately prosperous society in all aspects, particularly the northwest minority regions. Development is the general key to solving national problems. In September and October of 2013, Xi Jinping, the chairman of China proposed to construct "new silk road economic belt" and " 21 st-century maritime silk road", namely the strategic concept of "The Belt and Road" ("B\&R"). This concept pushes northwest minority regions to the leading edge of reform and opening-up from the margin. Northwest minority region has become the important node and key hub for interconnecting infrastructure and energy base construction, and the tourism of this region has ushered in an unprecedented development opportunity.

\section{A. To Drive the Local Economic Development, and Push the Targeted Poverty Alleviation in Northwest Minority Region}

Target poverty alleviation is one of the major strategic deployments in the new stage of China's poverty alleviation and industrial poverty alleviation is the key to targeted poverty alleviation. The poverty in northwest minority region is quite serious. As an emerging comprehensive industry, tourism is characterized by strong comprehensiveness and relevance, being able to drive the economic and social development. Northwest minority region has a long history, and its national culture develops in a diversified way. In the experience economy era, the charm of northwest minority culture attracts the tourists who pursue different culture deeply. In June 2014, in the 38th world heritage conference, it was announced that the transnational project of "Silk Road" applied jointly by China, Kazakhstan and Kyrgyzstan had passed the deliberation, and was listed into the World Heritage List, becoming the first project with transnational cooperation and success application for world heritage. This cultural route is 5000 kilometers long, totally having 33 relics, among them 22 relics are distributed in China, and 18 relics are distributed in northwest of China (7 in Shaanxi Province, 5 in Gansu Province and 6 in Xinjiang Uygur Autonomous Region) except 4 are distributed in Henan Province. Tourism industry has become the industry with the most development potential in northwest minority region. The development of tourism industry can inject new energy into the local economy, to promote economic growth, push the progress of regional economy integration. In addition, the promotion of the economy in northwest minority areas by tourism industry development also reflects in the employment settlement of rural surplus labor force. The economy of northwest minority region is quite backward, and the issue of surplus labor force is always outstanding. As a result, the development of tourism can increase the opportunity of employment, to relief the pressure on the city by rural surplus labor forces from certain level. Although the overall quality of some rural surplus labors is not high, they are the "professionals" in the special industry of tourism. The development of tourism industry has broadened the employment channel, solved the problem of survival of some labors, helped the ethnic minority areas to get rid of poverty and realize the leapfrog development, push the targeted poverty alleviation in ethnic minority areas, thus to build the moderately prosperous society together with the people nationwide.

\section{B. To Make a Positive Contribution to the Implementation of "The Belt and Road" Strategy}

Among the $22000 \mathrm{~km}$ of land boundary of China, 19000 $\mathrm{km}$ stretches in the ethnic minority areas, and 109 of the 138 counties (districts, cities) at the frontier are located in the ethnic minority areas. Among them, Xinjiang is the province with the longest borderline and the most border neighbors, having about a total of $5,400 \mathrm{~km}$ of borderline with neighboring countries, accounting about one fourth of China's total borderline with the neighboring countries. According to the statistics, in recent years, the total amount of products exported to the five countries of Central Asia from China's northwest area reaches more than half of the total exported volume of northwest region. The northwest minority region is closely linked to the Silk Road since the ancient times, and the masses of ethnic minorities have deep emotional identity towards the Silk Road. These areas and the neighboring countries are linked together by common mountains and rivers with common language, same culture and similar custom. The generality of culture constructs the bridge for communication among people of various countries along "The Road and Belt". The development of tourism industry in northwest minority areas can mobilize and gather the wisdom and strength of various nations, absorb and learn from historical experience, and serve the practices in contemporary era, so as to provide strong driving force for the construction of "The Road and Belt", strengthen the economic and cultural links among China and various countries of Central Asia and even the Europe, and make positive contribution to the promotion of implementation of "The Road and Belt".

\section{To Promote Cultural Exchange to Make the World Recognize China}

The complexity and diversity of national culture may result in mutual misunderstanding between the nations and countries, and even cause friction and conflicts, affecting the economic development. The northwest minority region is the region with more national problems. "Communication of Public Feelings" is the social foundation for the construction of "The Road and Belt". The research on the tourism industry development in northwest minority region is bound to promote cultural exchange, spreading and inheritance, which can carry forward the amicable cooperation spirit of the Silk Road. The "exchange, association and integration" of people in different countries, nations and regions, will make contributions to tourism diplomacy among neighboring countries, and enable the world to recognize China.

\section{PROBLEMS FACED BY THE TOURISM INDUSTRY DEVELOPMENT IN NORTHWEST MINORITY REGION}

The northwest minority region is located in the remote region with low development starting point, backward infrastructure. Although the state has given differentiated favorable policy to the northwest minority region, the labors, resources and funds of this region flow to the eastern developed regions continuously under the resource configuration mechanism with market playing the leading role, making the gap between this region and the developed regions 
larger and larger, resulting in many problems in the tourism industry development.

\section{A. Simple Tourism Product Structure, Low Degree of Industrial Intensification}

The northwest minority region not only has profound cultural foundation, but also has abundant natural resources, with many minorities and obvious tourism resource advantages. However, resource advantage does not equal to industrial advantage. The tourism product structure of northwest minority region is simple due to the limitations of geography, policy, economy and other factors. There are abundant products of village tourism and sightseeing tourism, but the products of leisure and vacation tourism, healthcare tourism and other high-end tourism products are very deficient. In addition, there is certain gap in terms of the accessibility between northwest minority region and the eastern developed areas, resulting in the low degree of industrial intensification and industrial efficiency. Taking the cost per capita per day of the tourists who enter into this region and stay overnight as example, such cost of northwest minority region is in the lower middle level nationwide, among them, the levels of Ningxia and Qinghai are the lowest.

\section{B. Backwards Tourism Management Mechanism}

Tourism mechanism reform of northwest minority region is backward when compared to that of eastern areas, and there is certain conflict between tourism and other related industries. The local economy, social culture and many other factors also restrict further reform and improvement of the tourism management system. Moreover, the functions convert slowly, the marketing degree of tourism development is low, and even some scenic spots are still led and managed by multiple leaders and multiple departments. All these have impacted the reasonable development and protection of tourism resources in the northwest minority region severely, which further influences the healthy development of the entire tourism industry.

\section{Lack of Funds for Tourism Development}

The special geographical location and economic development condition of northwest minority region determine the lower level of tourism industry investment and development as well as the shortage of tourism development funds in this region. It can be said that northwest minority region itself is short of funds with no external funds flow in. According to statistics, the investment in the tourism of China's western region in 2011 only accounts for $8 \%$ of such investment in the whole country. As of the end of 2013, the operation mileage of highway, railway, expressway and highspeed railway in the ethnic minority areas account for $23.84 \%$, $27.19 \%, 19.08 \%$ and $4.82 \%$ respectively of that of the whole country. Lack of tourism development funds and backward infrastructure has impeded the development of tourism industry in northwest minority region severely.

\section{Extreme Shortage of Tourism Talents and Other Soft Resources}

The soft resources in an area, such as the tourism talents, influence the planning and development of local tourism resources, formulation and implementation of tourism regulations, quality and reputation of tourism service, design and improvement of tourism reception facilities, as well as the quality of tourism personnel. Tourism education of northwest minority region is relatively backward with low technical reserve, and little investment in tourism education. Moreover, tourism talents flow to the eastern developed areas and no external talents are willing to come. Therefore, northwest minority region is extremely short of tourism talents.

\section{E. Fragile Ecological Environment}

Some areas of northwest minority region belong to the middle-heavy fragile ecological area and even extremely fragile ecological area. And they occupy very important position in the national ecological security strategic pattern, with high ecological importance, and quite a large part of areas belong to the national key ecological functional area or the prohibited development regions. The seventh central environmental protection and supervision group listed the ecological destruction of Qilian Mountain nature reserve into the issue list when reporting the supervision opinion to Gansu Province on April 13, 2017 (Liu Shixin, journalist of China Youth Daily and Chinese Youth Online). "General Secretary $\mathrm{Xi}$ Jinping pointed out that Gansu Province is the important ecological protective screen for the northwest region of China, holding importing position and playing significant role in safeguarding national ecological security. As a result, we shall strive to enhance the ecology and civilization construction level of this region." However, the "predatory" grazing, the construction of tourism development project without approval, and the launching of small hydropower project in recent years have laid heavy burden on Qilian Mountain ecology, and some destruction cannot be reversed. The backward economic development level has caused more short-term interests pursued by various beneficiaries of the tourism development.

\section{F. Traditional National Culture to Be Assimilated and Impacted}

There are many minorities in northwest minority region. Minorities have unique customs with plentiful traditional national culture attracting tourists from various places deeply. But in recent years, the tourism development has commercialized and vulgarized traditional national culture, and it has assimilated and influenced the culture. The protection, heritage and development of national culture have become the issue to be solved urgently for the tourism development in northwest minority region.

\section{CONCLUSION}

The construction of "The Road and Belt" strategic space and the "interconnection" construction along "The Road and Belt" have provided unprecedented new opportunity for the development of tourism industry in northwest minority region. "Interconnection" has improved greatly the transportation, 
logistics and other infrastructure of tourism as well as the pattern of opening up to the outside world, and strengthened the regional tourism cooperation. Tourism market is expanded constantly, tourism culture exchanges are increasingly frequent, and so the investment trade and other economic activities will increase sharply. Economy activity is enhanced, laying solid foundation for the realization of leapfrog development of tourism industry in northwest minority region.

\section{A. To Innovate Cooperative Development Concept, and Take Initiative to Participate in the International Tourism Development}

The new pattern for overall opening up created by "The Road and Belt" conception has brought about new ideas for international cooperation and regional development, for example, the concept of multilateral win-win cooperation, the concept of opening up with unprecedented tolerance, the concept of development with balance and coordination and so on. The coordination development of tourism area has become one of the manifestations of the tourism industry internationalization. Northwest minority regions shall give full play to the cooperation between government and the industry, innovate cooperation development concept, drive the cooperative development of tourism area and give play to margin advantage, to make northwest minority region become the leading edge of the regional tourism cooperation of "The Road and Belt" both at home and abroad, so as to strengthen the tourism cooperation with surrounding regions and promote regional common development and harmonious development.

\section{B. To Deepen Tourism System Reform}

Deepen tourism system reform, transform governmental functions, establish effective tourism management system and supervision mechanism, establish and improve the industrial self-management organization. Give full play to the role of market, and set up market competitive mechanism.

\section{To Excavate the Connotation of National Culture Thoroughly, Speed up the Transformational Upgrading and Innovation of Tourism Products}

The sole of ethnic tourism is national culture. The culture of northwest minorities has profound foundation and high taste. We should excavate the connotation of national culture thoroughly, develop characteristic tourism vigorously, to form the tourism products with national characteristics, culture characteristics and territorial characteristics, and speed up the transformational upgrading and innovation of tourism products.

\section{To Integrate the Tourism Resources of Northwest Minority Regions Fully to Form the Interaction Effect}

The tourism resources of northwest minority regions are of certain replaceability. We should integrate various kinds of resources fully and convert the substitutional relationship to complementary relationship, to form join forces, avoid homogenous development, vicious competition and other phenomenon, so as to realize symbiosis and complementation, form the interaction effect, and enhance the competitiveness of tourism industry of northwest minority regions in the markets of domestic and foreign countries.

\section{E. Implement the Talent Strategy}

In order to develop tourism in northwest minority region, the tourism talent strategy is urgently to be implemented. We should strengthen the leading role of the government to form new tourism talent compete mechanism through governmental promotion. The construction of tourism colleges should also be strengthened in northwest area, so as to improve the quality of local residents and tourism personnel through education and training. The employment environment of the tourism personnel should be improved, to not only attract talents, but also retain the talents, thus to solve the problem of lack of tourism talents and technology in northwest minority region.

\section{REFERENCES}

[1] Liu Lu, Wang Zhenzhen. 40 Years of China Tourism Research: Reflection and Forward-looking ---General Overview of China Tourism Research Annual Meeting of Tourism Tribune 2017 [J]. Tourism Tribune, 2017, (12). 刘鲁、王臻真.中国旅游研究 40 年: 反思与前瞻 一 2017 《旅游学刊》中国旅游研究年会会议综述 $[\mathrm{J}]$. 旅游学刊, 2017 年第 12 期.

[2] Dou Kailong. Research on the Development Mode of National Culture Tourism Industry in Northwest Region [M]. Lanzhou: Gansu Cultura Publishing House, 2015.12. 窦开龙.西北地区民族文化旅游产业发展 模式研究[M].兰州：甘肃文化出版社，2015.12.

[3] Jin Liqun, Lin Yifu. "The Belt and Road" To Lead China [M]. Beijing: Chinese Literature and History Press, 2015.10. 金立群、林敦夫. “带一路”引领中国[M].北京：中国文史出版社，2015.10

[4] Ma Binbin, Lu Xiaobo, Guodi, Ding Yujuan. Study on the Cooperation Development Strategy of Tourism in Five Provinces in Northwes Region under the Background of "Silk Road Economic Belt" [J] Economic Research Journal, 2015, (5). 马斌斌、鲁小波、郭迪、丁王 娟.“丝绸之路经济带”背景下西北五省旅游协同发展战略研究 [J].经 济学研究, 2015, (5).

[5] Wang Hongye. Research on the Advantages of Silk Road Tourism Development in Northwest Region [J]. Financial Review, 2015, (17). 王 虹烨.西北丝绸之路旅游开发的优势及对策研究 [J]. 金融观察, 2015, (17).

[6] Tan Bin, Wang Kehui. Study on the Integration of National Cultural Tourism Resources in Northwest [J]. Journal of North Minzu University (Humanities and Social Sciences), 2016, (9). 谭斌、汪克会.西北地区 民族文化旅游资源整合研究 $[\mathrm{J}]$. 北方民族大学学报(哲学社会科学 版)，2016，(9).

[7] Wang Jiaguo, Wu Zhongjun. Study on Innovative Tourism Development in Ethnic Minority Areas under the Background of "The Belt and Road" [J]. Guangxi Teachers Education University (Humanities and Social Sciences), 2016, (11). 王佳果、吴忠军. “一带 一路” 背景下民族地区旅游业创新发展研究 [J].广西师范学院学报 (哲学社会科学版), 2016, (11)

[8] Jin Menglu. Analysis of the Relationship between "The Belt and Road" and the Economy of Northwest Minority Region [J]. Business, 2016, (11). 靳梦露. “一带一路” 与西北民族地区经济关系浅析 [J].商, 2016, (11).

[9] Wang Zhengwei. Ethnic Minority Areas shall Play an Important Role in Serving the Overall Strategic Situation of "The Belt and Road" [J]. Minzu Tribune, 2015, (7). 王正伟. 民族地区要在服务 “一带一路” 战 略大局中大有作为 $[\mathrm{J}]$. 民族论坛，2015，(7).

[10] Research Group of Beijing Dianfeng Zhiye Tourism \& Culture Creativity Co., Ltd. Innovative Development of "The Belt and Road" Tourism [M]. Beijing: Beijing Tourism Education Press Co., Ltd., 2016.02. 北京巅峰智业旅游文化创意股份有限公司课题组. “一带路” 旅游创新发展 $[\mathrm{M}]$. 北京: 北京旅游教育出版社有限责任公司, 2016.02 .

[11] Jiang Lihui, Feng Gang. "The Belt and Road---Significant Strategic Opportunity of the Ethnic Minority Areas" [J]. China's Ethnic Groups, 
2015, (5). 蒋利辉、冯刚. “一带一路” , 民族地区的重大战略机遇 [J].中国民族，2015，(5). 